\title{
Improvement of the Methodological Approach to the Integrated Assessment of the Financial Strength of Commercial Banks
}

\author{
Svetlana Viacheslavovna Zenchenko \\ Department of Finance and Credit, North Caucasian Federal University, Stavropol, Russia \\ E-mail: zen_sveta@mail.ru
}

\section{Doi:10.5901/mjss.2015.v6n5s4p98}

\section{Abstract}

In today's circumstances of the increasing competition in the domestic and international financial markets, constantly changing external factors, in which commercial banks operate, require an in-depth assessment of their financial strength and finding ways to improve it. The article describes the theoretical aspects of the economic category "financial strength of a commercial bank," singles out the basic principles of the sustainability assessment of a credit institution, as well as formulates the problematic issues of development of the methodical approach to the assessment of the financial strength of a commercial bank, marks the milestones, groups the assessment criteria and types of credit institutions with respect to the analyzed indicators, and formulates the basic requirements and recommendations.

Keywords: commercial bank, financial strength, methods of assessment of financial strength, financial strength indicators, financial strength monitoring, rating models, Basel requirements.

\section{Introduction}

Current trends in the banking sector have confirmed the need to pay more attention to the issues of strength and reliability of the financial business, due to the instability of the global environment and often unjustified risks of operations of a credit institution. All this imposes serious requirements for ensuring the financial strength of financial and credit institutions, as well as the efficiency and accuracy of the methods for its estimation.

However, the applied methodology for the financial strength assessment is mainly intended for internal use by banks, preventing all interested users-the market participants-from obtaining timely and unbiased information to assess the financial position of the bank based on published statements with reasonable validity.

In economic literature, the issues related to the assessment of the financial strength of banks were approached by Pierre L. van den Berghe, Sonja Brajovic Bratanovic, Hennie van Gruening, Aristóbulo de Juan, P.S. Rose, R. Sahajvala, Joseph Sinkey Jr., Iu.S. Maslenchekova, S.N. Panevina, V.lu. Polushkin, M.A. Pomorina, and other academic economists.

However, despite the significance of the performed research, it should be noted that insufficient attention has been paid in the works of Russian and foreign scientists to the integrated assessment of the financial strength of a commercial bank and its monitoring. The existing traditional approaches to the assessment of the financial strength and reliability of credit institutions need substantial transformation with account of the specifics of the modern analytical tooling, the requirements of the Basel Committee, the compliance with optimal proportions of return, risk, and liquidity to ensure stable position of a credit institution in the banking market. The urgency and insufficiency of the scientific study of the methodological approaches to the assessment of the financial strength of commercial banks determined the choice of the research topic.

The financial strength of a commercial bank is the stability of its financial position in the long term and reflects the state of its resource base, in which the credit institution in the process of redistribution of its resources is able to ensure smooth operation and to receive the predetermined amount of income and profit. Securing the financial strength of a commercial bank improves its financial independence and attractiveness for customers that ultimately allows raising additional resources, growing the resource base, expanding the sphere of investments, developing new services, and making bigger profits.

To achieve the analytical goals and assess the prospects of the banking system development, it seems logical to define the financial strength of a commercial bank by identifying the typological groups based on the ratio analysis method. The advantage of this approach is the leveling of the experts' subjective assessments of the positions held by 
the credit institution.

\section{Method}

Assessment of the financial strength of a credit institution, in our opinion, should be done with account of the following binding principles:

- Universality, which implies the use of this technique for any commercial bank without taking into account the specifics of its profile and region;

- Consequentiality, comprising implementation of the technique in certain stages;

- Systematicity. which requires covering and taking into account all the characteristics and features of the credit institution to obtain valid results;

- Significance of the results obtained during the implementation of each stage, and their possible application in the future;

- Flexibility, assuming the possibility of changing the system of indicators and criteria for evaluating at the change of the economic situation or substantial specificity of the object of study.

The proposed methodological approach to defining the financial strength of a commercial bank assumes the following stages that are presented in Figure 1.

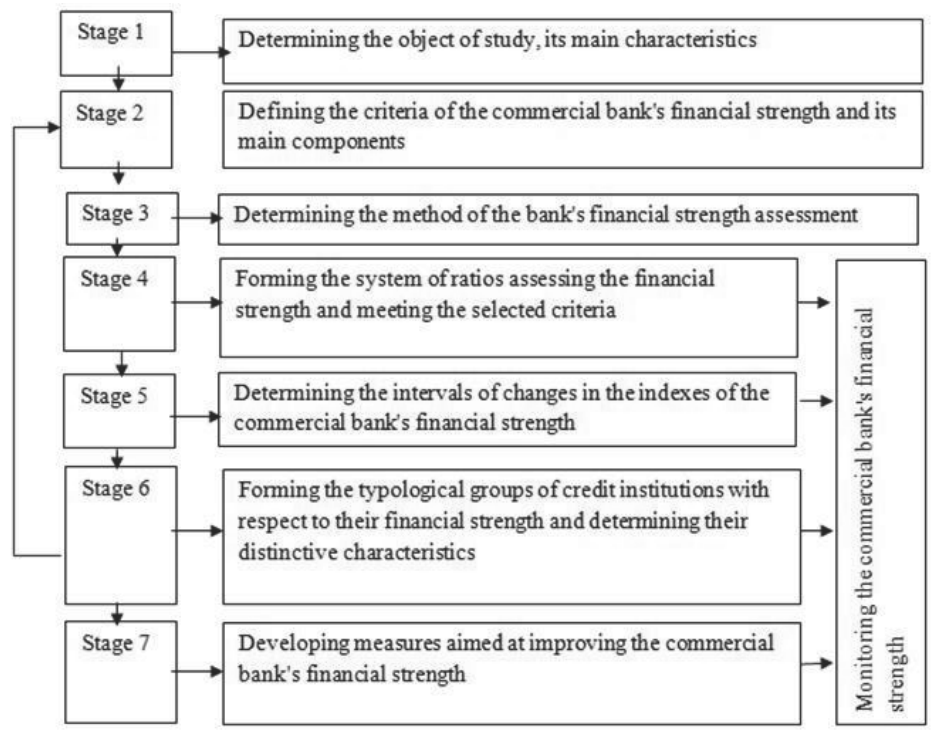

Figure 1. Stages of assessing the commercial bank's financial strength

In the first stage, the study of the credit institution as an object for analysis of its financial strength and the banking market as a whole is performed. The bank is a specific organization, the main service of which is money in its different forms. This feature imposes a significant specificity for the market of banking services, a set of criteria and factors that characterize the effectiveness of the management of its own and borrowed funds and are used to assess the financial strength of the bank.

At the second stage, the selection and rationale of criteria of the financial strength of commercial banks is performed. The performed studies specified the following criteria of the financially stable operation of a commercial bank: the bank's capital base, liquidity, profitability, quality of assets and liabilities. For their evaluation, it is planned to use the system of analytical factors.

At the third stage, the assessment methods are determined. As a general rule, several analytical methods (methods) are applied to assess the commercial bank's financial strength, depending on the assigned goals and objectives. The most commonly used ones are the ratio analysis, statistical, and expert methods of assessment. 
Using the statistical methods of analysis (selection, grouping, observation, comparison) allows exploring and breaking up the totality of commercial banks within a certain time interval into individual typological groups, identify their peculiarities, problems, formulate perspectives, identify the place (role, contribution) of each object in the general population or a selected group. As part of the statistical methods, the mono-parameter and multi-parameter grouping is applied, which allows to compare the obtained groups (types, classes) by various parameters.

In the world practice, there is a variety of approaches to the assessment of financial strength, which can be divided into the following groups:

1) Rating systems, based on qualitative and quantitative indexes (CAMEL, ORAP, PATROL);

2) Systems of assessment of risks and the degree of the bank's resistance to them (RATE, RAST);

3) Statistical models that evaluate the effectiveness of the bank's operation (FIMS, SAABA).

The most common rating system is the PATROL technique used by the Bank of Italy since 1993. It is designed for a remote analysis of the financial position of a credit institution. A different approach is implemented within the framework of the French rating system ORAP (Organization and Reinforcement of Preventive Action). The purpose of this multifactor system is to reveal significant problems in the bank based on the assessment of all components of the risks associated with its activities using quantitative and qualitative information. It consists of 14 indicators divided into five groups: the prudential ratios (capital, liquidity, etc.); the on- and off balance sheet activities (assets quality); the market risk; the income; the qualitative criteria (shareholders, management and internal control). The CAMEL is the most popular ranking system assessing the reliability of commercial banks in the world. It was designed for the Federal Reserve to oversee banking activities and is based on five integrated indicators (Giliarovskaia and Panevina, 2003; Tatarinov, 2013:

- Capital adequacy;

- Assets quality;

- Management factors;

- Earnings;

- Liquidity.

Each of them, in turn, includes more detailed indexes that are also evaluated on a 5-point grading scale. The result of the implementation of this technique is the identification of the groups of reliability of banks depending on the status of all its evaluation criteria.

Systems that are based on the ratio analysis include the BaKred System (BAKIS) used since 1997 by the Central Bank of Germany. This technique assesses the activities of credit institutions from the standpoint of exposure to the credit, market, and liquidity risks on the financial position on the basis of 47 ratios.

In 1997, in the UK, in order to assess the financial strength of banks, they developed the RATE system, which includes three interrelated blocks: risk assessment, assessment of the effectiveness of supervisory tools, and the supervisory tools themselves. Risk assessment includes indexes describing the risk categories of the banking business (related to credits, market, interest rates) and the effectiveness of control over them. The next step is the development for each bank of specific supervision tools, programs, and mechanisms for the effective implementation of supervision functions.

In the Netherlands in 1999, in order to assess the reliability and financial strength of a credit organization, they developed the RAST (risk analysis support tool) technique based on the assessment of the level of risks assumed by the bank and including four stages: an analysis of the financial statements of the credit institution; allocation of units or activities of the credit institution; risk assessment and control of the quality of individual units; aggregation of indicators and reporting.

Assessment of the bank's strength by the FIMS (financial institutions monitoring system) technique is carried out in two stages. At the first stage, the FIMS rating is determined based on 30 factors, evaluating the current position of the bank. In the second stage, the FIMS risk is calculated based on a forecast of the condition of the bank, its resistance to the environmental impact over the past two years.

The French Banking Commission has developed a system of the banking analysis support-SAABA—consisting of three diagnostic modules. The first module is the module of quantitative analysis assessing the loan portfolio and the probability of default of different types of loans. The second module examines the quality of the bank's shareholders (including the willingness of the legal entities and individuals to support the credit institution). The third module diagnoses the quality of bank management, the in-house control system, and liquidity. Using the information obtained in all three modules, the system generates a synthetic diagnosis of the bank, including an assessment of its reliability (on a 5-point grading scale).

It can be concluded that the main disadvantage of the considered methodologies for assessing the bank's financial strength is that they allow reliably estimating only the current financial position of a bank without the forecast for the 
future. And it should be noted that despite the diversity of valuation methods, no model has yet been created that would accurately and adequately assess the commercial bank's financial strength.

It should be noted that all the presented techniques are based on the ratio approach. The ratio analysis method is the most common, traditional method for assessing the financial strength of a commercial bank, which is used to determine the quantitative relationship between items, sections, or item groups of the balance sheet based on the published financial statements and the developed system of analytical coefficients (the proprietary or legally approved one). With this method, it is possible to calculate the relative impact of changes in the volume of raised and placed invested resources, profitability and cost-effectiveness of the credit institution, which allows evaluating the efficiency and financial strength of commercial banks.

The expert methods allow assessing the qualitative characteristics of a commercial bank, taking into account the specificity of the indexes reflecting the activities of commercial banks and their significance for the assessment.

Economic and mathematical modeling is the process of describing the efficient allocation of raised and invested funds with account of the liquidity, cost-effectiveness, and specificity of the credit institution with the help of mathematical models. Mathematical models are the most efficient means of solving the tasks of optimization of the reliability of a commercial bank, allowing to estimate the intensity of the planned tasks, determine the limiting group of resources, their scarcity, etc.

In the fourth stage, a system of the commercial bank's financial strength indexes is formed. Theorists and practitioners in the banking field have not developed a unified approach to the set or system of ratios that would best characterize the degree of the bank's financial strength. Within the framework of this study, the task was to develop a system of ratios that would meet the following requirements:

- Total reflection and accounting of all activities of the bank in the criteria of financial strength;

- Simplicity, consistency, ease of calculation;

- Consistency with the regulatory requirements of the Bank of Russia and other regulators.

Economic phenomena, especially in the banking practice, are quite complex, so they cannot be expressed with a single individual ratio. Taking into account the nature of banking activities, building a system of ratios should be based on the following methodological principles:

- Complexity, i.e. comprehensive assessment of the commercial bank's financial strength, but not just a characteristic of individual components;

- Determination of the financial strength by the key parameters of banking activity: profitability, capital base, liquidity, asset quality, operations' risks;

- Comparability and adequacy of the indicators used in the assessment;

- Universality, i.e. accessibility for any commercial bank.

Traditionally, the commercial bank's financial strength is determined based on the system of indexes developed by rating agencies (Banki: predlozheniia po izmeneniiu metodologii prisvoeniia reitingov [Banks: proposals of changes in the methodology for assigning ratings]; Kreditnye reitingi. Protsedura prisvoeniia reitinga [Credit ratings. The procedure for assigning the rating]). These include the group of equity capital indexes, the group of bank assets indexes, the group of bank liabilities indexes, as well as the groups of the bank's liquidity, income/expenses, profitability/cost-effectiveness.

At the present time, understanding the importance of the issue of diagnosing the financial strength of banks, in the newly developed Basel III standard, experts have introduced a number of ratios that allow assessing the quality of funding the working assets of banks, and the banks' ability to protect themselves from risks using the base part of the equity (Basel III: The Liquidity Coverage Ratio and Liquidity Risk Monitoring Tools). Therefore, the previously used set of ratios assessing the financial strength of banks has been complemented by a number of new indexes.

The Basel III standard has proposed the net stable funding ratio, which allows to evaluate the banks' ability to withstand external market shocks and is calculated as a ratio of total time-deposit borrowings to total risk assets (Basel III: Long-term Impact on Economic Performance and Fluctuations. Bank for International Settlements). The stable financing is based on the equity capital and borrowed deposited funds, which are a reliable source of funding. The crisis has shown that the higher the amount of non-deposit liabilities in the bank's liabilities is, the more the bank is vulnerable to a worsening external environment, which manifests itself in a sudden increase in the cost of funding or decrease in its availability. The net stable funding ratio contributes to a more accurate assessment of the liquidity risk for all on- and offbalance sheet items.

Another important index is the index that assesses the coverage of the operating assets with the equity, which in this case is not synonymous with the capital adequacy ratio. The ratio proposed by Basel III experts is only a part of the capital adequacy ratio and allows assessing the bank's ability to withstand the market risk due to the stable part of its 
equity. This indicator is calculated as the ratio of the core capital to assets weighted by the amount of risk (net assets) the higher the given ratio, the stronger the position of the assessed bank is.

It should be noted that the Russian practice of banking activities is different from that of European countries, first of all, with the fact that the main sources of liabilities formation are the funds of legal entities and individuals, but not the funds raised on the stock market. Therefore, the index of sustainable funding in the form, in which it is offered in the Basel III standard, becomes irrelevant in the Russian reality.

The Bank of Russia, defining the economic position of commercial banks, evaluates: capital; liquidity; assets; income; mandatory standards established by the Instruction of the Central Bank of the Russian Federation "On Mandatory Standards of Banks" \#139-I; quality of management; transparency of the bank's ownership structure.

Thus, the factors that determine the financial strength of a commercial bank can be grouped as follows:

- Ratios of the bank's capital base;

- Liquidity ratios;

- Profit margins;

- Effectiveness ratios;

- Ratios of assets and liabilities' quality;

- The net stable funding ratio.

In practice, for estimating the given ratios, a sufficiently large number of ratios are applied. Therefore, it is necessary to select from the variety of ratios those that have the greatest impact on the financial strength of the bank. Selection of coefficients should be based not on subjective judgments of analysts, but on determining strict dependence of the financial strength of banks on these ratios and on getting rid of the multicollinearity effect.

In this regard, the proposed ratios form a certain integrated system fully and optimally revealing the activities of a commercial bank and assessing its financial strength.

In the fifth stage, the definition of a trend of the changes in the financial strength indexes of a commercial bank takes place. The point of this stage is the formation of an interval of values of financial strength, development of an analytical scale, and allocation based on the calculated typological groups (classes) of credit institutions with respect to the tested criterion.

At the sixth stage, the typological groups of credit institutions are formed with respect to their financial strength, and their distinctive characteristics are determined.

Based on the performed study, we allocated four typological groups of credit institutions with respect to their financial strength: absolutely financially stable; financially stable; conditionally financially stable; financially unstable.

If a commercial bank is included in the group of absolutely financially stable commercial banks, it evidences that the bank meets absolutely all requirements and liabilities, is stable in all business areas, as well as resistant to the external impact factors, has a sufficient resource base and good relationships with customers, and its management system is effective.

If a commercial bank is included in the group of financially stable commercial banks, it indicates that the bank generally meets all the requirements and liabilities, but its resource base tends to decrease, there are shortcomings in the liquidity position, and the methods and style of management are not efficient enough, but at the same time the bank's operation is stable and it can successfully adapt to various fluctuations in the external environment.

If a commercial bank is included in the group of conditionally financially stable commercial banks, it shows that there are financial issues, a limited resource base for the fulfillment of commitments to customers; the bank is vulnerable to adverse changes in the economic environment and needs intervention of banking supervision bodies with the aim of leveling the issues of the bank's activities to ensure the financial strength of its operation.

If a commercial bank is included in the group of financially unstable commercial banks, it indicates a high probability of bankruptcy of the bank, tangible problems in the resource base, and the lack of liquidity to meet obligations to customers (Gogol', 2011). For banks put to in this group, the external problems are so serious that completely paralyze its operation and require urgent financial owners' support or support from alternative financial sources. Therefore, without corrective measures, such a bank is likely to be liquidated or absorbed by a more sustainable one.

The final step is to develop a system of measures aimed at improving the commercial bank's financial strength. These include recommendations allowing the owners and management of commercial banks placed in a certain typological group by the degree of financial strength to develop a program for improving the bank's position.

It should be noted that the bank regulatory authority can influence on the selected criteria of financial strength using the tools of monetary policy and various methods. These tools and methods may include: establishing rules and regulations governing the activities of the commercial bank; supervising the commercial bank's activities; establishing and 
monitoring the compliance of the commercial bank with mandatory standards; determining the reserve requirements (reserve requirements standards); setting interest rates on the bank's operations; implementing foreign exchange interventions; refinancing credit institutions.

As part of stages 4-7, the activities for the monitoring of the financial strength of a credit institution are carried out, which is a process of continuous science-based diagnostic and prognostic monitoring and analysis of changes in the commercial bank's financial strength in order to ensure its stable and reliable operation and development. The results are the basis for taking corrective measures in the field of the banking policy of assets and liabilities management, risk management, and liquidity.

Thus, as part of the performed study, we formed a methodological approach to the assessment of commercial bank's financial strength, and consistent abidance by its steps will allow carrying out this assessment and obtain objective results.

\section{Results}

An integrated assessment of the commercial bank's financial strength includes the application of criteria, which give the most accurate information about its level, direction, and the trend of changes. At the same time, economics has finally formulated the approaches to justifying the choice of indexes, methods of their calculation, determination of trends of changes, etc. Currently, the most common methods of integrated assessment are the rating or ranking models based on the procedures of combining indicators characterizing individual segments of the bank's operation.

The stages of integrated assessment of the financial strength of a credit institution are summarized in Figure 2.

An increase (decrease) in the integral index of commercial bank's financial strength over time demonstrates the increasing (decreasing) level of financial strength and reliability of its operations, and is characterized by a positive (negative) change in the function of the integral index. Consequently, the growth rate of the commercial bank's financial strength is associated with the positive gain in the integral criterion during the base period $\left(I_{s}(t+1)\right)$ compared with the previous period $\left({ }^{I_{s}(t)}\right)$ :

$$
I_{s}(t+1)>I_{s}(t)
$$

In economic literature, there are no common approaches and methodologies for the development of an index of integrated assessment of the commercial bank's financial strength. The problem of its development is that it is necessary to, first of all, determine the range of indicators that reflect the financial strength (instability) of the bank's operation; secondly, combine the multidirectional and multidimensional parameters, thirdly, harmoniously combine all the components of the financial strength, etc.

Given that each of the blocks of ratios that together characterize the financial strength can be quantified through the internal indexes, at their justification, it is very important to comply with the following requirements:

- Systematicity -it reflects the interrelation and mutual subordination between different indexes, without which it is impossible to identify the cause-and-effect relationships between the individual elements of the bank's financial strength, as a complex multi-component system, and to get the most accurate picture of the object under study;

- Measurability, i.e. the indexes used for the analysis must be quantifiable;

- Adequacy, i.e. the reported data should be accurate, and measurement errors must not lead to a distortion of the results;

- Comparability, i.e. the indexes used in the calculation must comply with the unity of the value-related and structural factors, time intervals, for which the compared indexes have been calculated;

- Reducibility, i.e. the indexes must be bound by the cause-and-effect relationship to the studied attributes and be mandatory for the calculation;

- Reliability-the method of collecting and processing the initial information allows checking the accuracy of the data;

- Orientation-it indicates that the change in the value of each of the indexes of financial strength must lead to a respective increase or decrease in the integral index.

In the absence of generally accepted assessment standards within the framework of this study, we propose the following approach to the definition of the integral index of the commercial banks' financial strength, based on the assessment of all of its components: the resource and operating components, the position by efficiency and profitability, liquidity, etc. 
The integrated assessment of the commercial bank's financial strength within the context of this work is understood as the assessment of the reliability of the credit institution's operation from the viewpoint of a coherent combination of the main aspects: resources, assets and liabilities management, cost-effectiveness, the Basel Committee's recommendations.

The implementation of the developed approach will reveal the existing disparities in the commercial bank's operation in its various aspects.

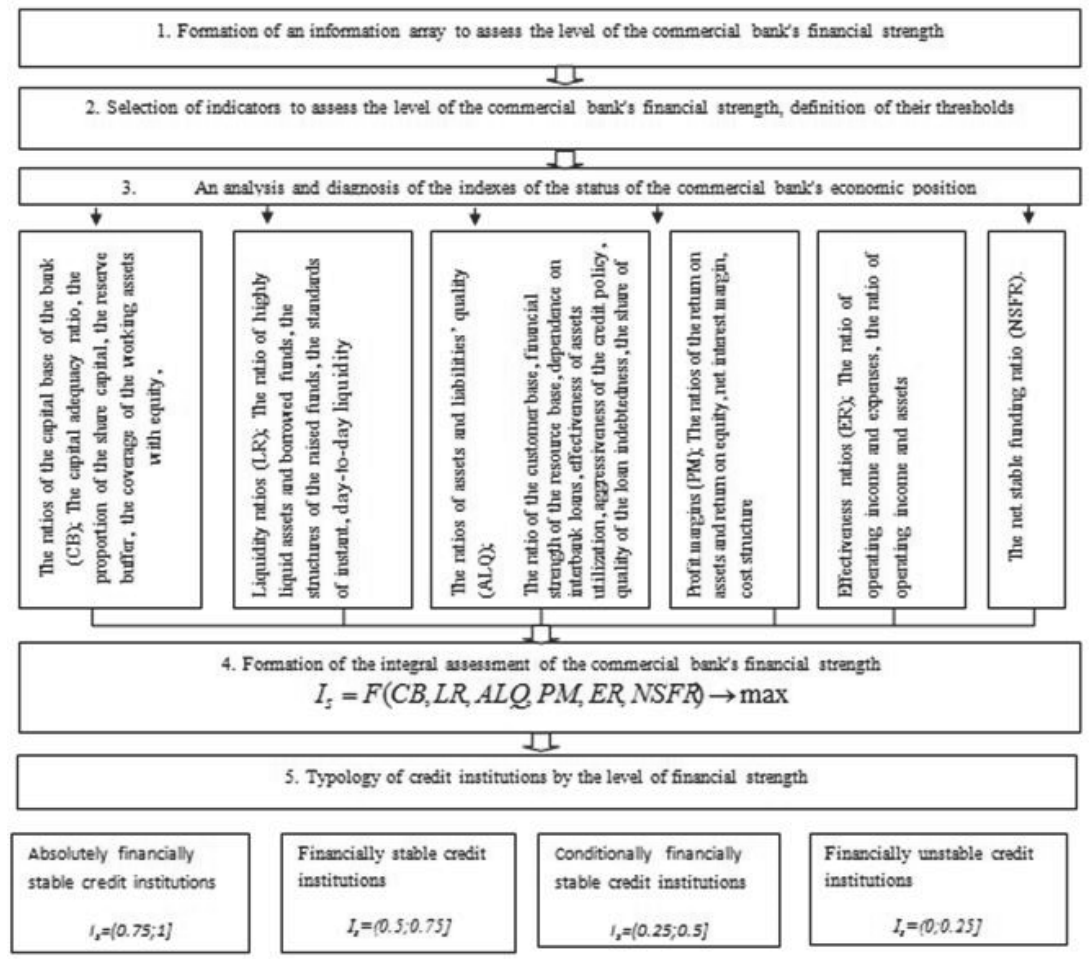

Figure 2. The technique of integral assessment of the commercial bank's financial strength

\section{Discussion}

The methodology of the multidimensional economic and statistical analysis makes it possible to obtain the most accurate assessment, using six groups of indicators, as of a given date, comprehensively characterizing the commercial bank's activity. For each block of indexes, the indicator is calculated, based on which the integrated index of financial strength of the credit institution is calculated.

The significant moment in this case was the definition of the form of the integral index of financial strength of the bank. Most often, the financial strength indexes are calculated in the form of the arithmetic mean of private indicators. However, within the meaning of the considered integral index, it is more consistent with the geometric mean that reflects the proportionality between the indices. In addition, the considered indicators allow reflecting the real situation that is emerging in the bank. An integral indicator of the commercial bank's financial strength can be calculated by the following formula:

$$
I_{s}=\sqrt[6]{I_{C B} \times I_{P M} \times I_{A L Q} \times I_{L R} \times I_{E R} \times I_{N S F R}},
$$

where $I_{s}$ is the level of financial strength of the commercial bank;

$I_{C B}$ is the level of the capital base of the bank;

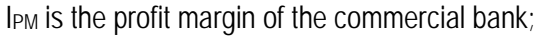




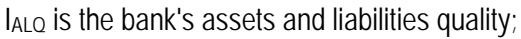

$\mathrm{ILR}_{\mathrm{R}}$ is the liquidity ratio of the commercial bank;

IOE is the level of operating efficiency of the commercial bank;

INSFR is the level of net stable funding.

This formation of the integral index will allow taking into account the significance (contribution) of each of the components of the financial strength of a credit institution at performing the target function. A change in any of the included indicators leads to a change in the value of the integral index of the financial strength of the bank.

Given that the selected indicators are not proportionate, they should be standardized based on the methods for normalization and variation range of ratios, which will allow reducing them to a single numerical measurement, ranging between 0 and 1.

In conclusion, we should note that the proposed approach allows obtaining a relative assessment of the financial strength of a commercial bank and reflecting its position in the market of banking services. The proposed method for calculating the integral indicator of the financial strength has a certain sensitivity and informativeness.

\section{References}

Banki: predlozheniia po izmeneniiu metodologii prisvoeniia reitingov [Banks: proposals of changes in the methodology for assigning ratings]. Retrieved from: Http://www.standardandpoors.ru/_Images/Pdfs/6634.pdf [in Russian].

Basel III: Long-term Impact on Economic Performance and Fluctuations. Bank for International Settlements. February 2011. Retrieved from: http://www.bis.org/publ/work338.pdf.

Basel III: The Liquidity Coverage Ratio and Liquidity Risk Monitoring Tools. Bank for International Settlements. January 2013. Retrieved from: http://www.bis.org/publ/bcbs238.pdf.

Cosimano, T.F., \& Hakura, D.S. (2011). Bank Behavior in Response to Basel III: A Cross-Country Analysis. International Monetary Fund. May 2011. Retrieved from: http://www.imf.org/external/pubs/ft/wp/2011/wp11119.pdf.

Giliarovskaia, L.T., \& Panevina, S.N. (2003). Kompleksnyi analiz finansovo-ekonomicheskikh rezul'tatov deiatel'nosti banka i ego filialov [A comprehensive analysis of the economic and financial performance of a bank and its branches]. Moscow [in Russian].

Gogol', D.A. (2011). Problematika finansovoi ustoichivosti kommercheskogo banka i metodov ee otsenki Volgograd [The problematics of the financial strength of a commercial bank and methods of its assessment]. Vestnik Volgogradskogo gosudarstvennogo universiteta - Herald of the Volgograd State University, 2(19), 163-167.

Korporativnoe upravlenie bankami: metodika kreditno-reitingovogo agentstva [Corporate governance of banks: Guide of the credit-rating agency]. Moody's investors service. European Bank for Reconstruction and Development. Retrieved from: http://www.ebrd. com/downloads/legal/corporate/moodyr.pdf.[in Russian].

Kreditnye reitingi. Protsedura prisvoeniia reitinga [Credit ratings. The procedure for assigning the rating]. Retrieved from: http://www.standardandpoors.ru/page.php?path=process [in Russian].

Muraviev, A.K. (2008). Finansovaia ustoichivost' kommercheskogo banka: metodicheskii aspekt [Financial strength of a commercial bank: the methodical aspect]. Novosibirsk.

Sorokina, I.V. Sovershenstvovanie podkhodov $k$ otsenke finansovoi ustoichivosti bankov [Improvement of approaches to assessing the financial strength of banks]. Retrieved from: http://www.bankir.ru [in Russian].

Tatarinov, L.V. (2013). Kriterii otsenki finansovoi ustoichivosti kommercheskogo banka s pozitsii sub"ektnogo sostava rynka [Criteria for assessing the financial strength of a commercial bank from the position of the subject structure of the market]. Izvestiia Irkutskoi gosudarstvennoi ekonomicheskoi akademii - News of Irkutsk State Academy of Economics, 3.

Tiniakova, V.I., \& Mnatsakanian, Sh.V. (2011). Metody prognozirovaniia finansovoi ustoichivosti kommercheskikh bankov [Methods of forecasting the financial strength of commercial banks]. Sovremennaia ekonomika: problemy i resheniia - Modern Economy: Problems and Solutions, 5(17), 27-36 [in Russian]. 